Article

\title{
Determinants Linked to Family Business Sustainability in the UAE: An AHP Approach
}

\author{
Mohammed Oudah, Fauzia Jabeen * (D) and Christopher Dixon \\ College of Business, Abu Dhabi University, P.O. Box 59911, Abu Dhabi, United Arab Emirates; \\ moudah20@gmail.com (M.O.); christopher.dixon@adu.ac.ae (C.D.) \\ * Correspondence: fauzia.jabeen@adu.ac.ae; Tel.: +9712-5015-662
}

Received: 9 December 2017; Accepted: 15 January 2018; Published: 18 January 2018

\begin{abstract}
The purpose of this study is to identify and prioritise the various success factors linked to the sustainability of large and medium sized family businesses (FB) in the United Arab Emirates (UAE). A well-researched methodology was used for the synthesis of priorities and the measurement of consistencies. The analytic hierarchy process (AHP) model was developed with seven criteria and 15 sub-criteria gleaned from prior research. Data were collected using an interview-based survey conducted on twelve medium and large sized family firms in the UAE. The data collected were interpreted and a priority vector was assigned. The findings show that large family businesses in the UAE are aware of transition failure and have long-term planning for their future generations in place; however, they need to give more importance to family values and family capital. On the other hand, medium sized family businesses are less aware of transition failure and have limited long-term planning; they are more concerned with short-term returns. Therefore, they need to create and give more importance to succession planning, strategic planning and corporate governance to ensure their business longevity. The study highlights multi-generation family business sustainability, and identifies the major determinants that the family members and business leaders need to consider for their business continuity and survival. The model can be utilized by academics in family business sustainability studies. The findings interpreted can help policy makers and related associations develop various policies based on the specific factors found to run the family businesses in a sustainable manner. The research model had limited dimensions and the findings cannot be generalized. This study is the first to study the determinants of family business sustainability in the context of the UAE using the AHP model.
\end{abstract}

Keywords: family business (FB); large and medium sized enterprises; sustainability; analytic hierarchy process (AHP); United Arab Emirates (UAE)

\section{Introduction}

Family businesses (FBs) are the backbone of economic growth in both industrialized and developing countries [1], they play a significant role in the national economic development and sustainability worldwide [2] facilitating wealth creation and economic stability [3]. FBs constitute greater than 80 percent of all businesses in the world of free economies [4]. Family enterprises contribute 70-90 percent of the global GDP, creating more than half of the total employment in the developed countries [5], and comprise of at least two-third of businesses worldwide [6]. Thus, the importance of FBs to the global economy should not be underestimated.

FBs have low survival rates [7] due to the various encountered challenges, such as increased market competition and business life cycle maturity, limited capital to satisfy business and family needs, weak leadership in succeeding generations, resistance to change, a lack of entrepreneurship, disputes between family successors and desperate family needs and goals [8]. Recently, scholars have 
started noticing the complexity of issues faced by these family enterprises [9], noting that only $30 \%$ of family-owned businesses transition to the second generation, only $10-15 \%$ transfer to the third generation, and only 3-5\% survive to the fourth generation [10-14]. Given these low survival rates, it is surprising how little research has been done on the subject of family business survival [15]. Therefore, family business owners and leaders need to be prepared to use the best strategies and practices to survive generational transition and sustain their businesses in the market economy.

\section{Research Landscape}

In the Gulf Cooperation Council (GCC), family businesses account for $80 \%$ of non-oil and gas GDP and more than $90 \%$ of the private sector, generating more than $70 \%$ of the employment in the region [16-18]. Similar to their GCC counterparts, $90 \%$ of the UAE private sector are family-owned businesses $[19,20]$. These statistics show the substantial importance of family business survival to the GCC economy.

Scholarly researchers and practitioners have proven that family businesses who follow the best practices stated in the literature last longer [8]. Long-term growth is established by applying those success factors which help to balance between the family and the business [21].

Even though FBs in the UAE are supported by the rapid economic growth of the country as well as the facilities provided by the government to encourage the development of family-owned businesses, a rather small number of family businesses succeed at surviving from generation to generation and, in this respect, the UAE is not different from the rest of the world [22].

Past researchers have published on a variety of family business related topics, including conflict, governance, innovation, gender, ethnicity, business performance, succession, the influence of family, family capital, leadership, management and extant theory $[9,23-26]$. This shows that some of the topics addressed are related to family business survival and sustainability. Prior researchers stressed that family firms need to operate for their long-term survival, success and growth [27,28], and have discussed the success factors for the long-term sustainability of a family business [29]. Nevertheless, few studies have combined all the major success survival factors in one research. Researchers usually discuss each success factor separately $[24,30]$. However, a major gap in all the previous research is that authors have not prioritized the importance of each success factor, by laying down all the known factors in the literature and investigating the current family businesses, particularly in the context of the United Arab Emirates (UAE). Therefore, this study is the first to combine all success factors reported in the literature to help UAE based family businesses to sustain themselves across generations. Hence, the research question of this study is: what factors should the UAE family businesses consider to prepare for their succession and long term sustainability?

This study considers the success factors stated in the literature, such as succession planning, strategic planning, corporate governance, leadership, family values, family capital, and family firm advisors, and examines the significance of each factor in large and medium family firms in the UAE. To be able to distinguish between the importance of each success factor/criteria and sub-criteria, an Analytical Hierarchical Process (AHP) is employed [31]. The results of this study would guide family business owners on the most important factors they need to concentrate on to ensure their business sustainability through many generations ahead. Therefore, the objectives of this research are:

(1) To identify the factors that influence the viability of a family business; and

(2) To prioritize the importance of factors such as succession planning, strategic planning, corporate governance, leadership, family business values, family capital and role of advisors in two different cases considering large and medium family businesses in the UAE.

The remainder of this paper is organized as follows: Section 2 discusses the literature linked to the success factors in family businesses and Section 3 presents the research methodology. The discussion of the research is carried out in Section 4. In Section 5, the paper concludes with implications and limitations followed by the directions for future research. 


\section{Literature Review}

\subsection{Family Business Definitions}

Scholars have not settled on a single definition of the family business. Wrotman [32] has highlighted more than 20 different definitions for family firms from the available literature. The main variation in the definitions of the family business is the level of involvement of the family in the firm's management. Therefore, the definitions of the family business have been categorized into two main groups by John Davis as follows: Structural definitions which highlight the firm's ownership or management structure, and Process definitions which identify the extent of the influence of the family on the business without direct involvement in its management [33]. In this study, the definition stated by the United Arab Emirates business sector will be used, which defines the family business as a business in which at least $51 \%$ of the shares are owned by a single family and at least one member of the management team is chosen from the owning family [34].

Enterprises in the UAE are classified into micro/small/ medium/large-sized depending on the number of employees working for them as presented in Table 1: if the number of employees working for a given enterprise is less than 5 , it is considered to be a micro enterprise; if this number ranges from 5 to 19 , the enterprise is considered to be small; if this number ranges from 20 to 49 , the enterprise is medium-sized; and enterprises employing 50 employees, or more are considered to be large [35].

Table 1. UAE enterprise categorization.

\begin{tabular}{cc}
\hline Enterprise Category & Number of Employees \\
\hline Micro & $<5$ \\
Small & $5-19$ \\
Medium & $20-49$ \\
Large & $\geq 50$ \\
\hline Source: (Statistics Centre Abu Dhabi, 2013).
\end{tabular}

\subsection{Family Business Developmental Stages}

The sequential stages of family business development noted by Gersick et al. [36] are shown in Table 2.

Table 2. The sequential stages of family business development.

\begin{tabular}{ccccc}
\hline Phase & Older Generation & Younger Generation & $\begin{array}{c}\text { Approximate } \\
\text { Business Age }\end{array}$ & Generation Leading \\
\hline Young Family Business & $>40$ years old & If present $<18$ years old & $<15$ years & First Generation \\
\hline $\begin{array}{c}\text { Independence of younger } \\
\text { generation entering the } \\
\text { family business }\end{array}$ & 33 to 55 years old & 13 to 29 years old & $<30$ years & First Generation \\
\hline Working Together & 50 to 65 years & 20 to 45 years & $<45$ years & $\begin{array}{c}\text { First and Second Generation } \\
\text { leading }\end{array}$ \\
\hline Passing the baton & Older than 60 years old & & $>45$ years & Second Generation leading \\
\hline
\end{tabular}

Source: (Gersick et al., 1997).

As the UAE celebrates its 45th national day [37], many of the medium and large sized family businesses are now in the first- and second-generation leading stage. This shows that the United Arab Emirates has reached the critical stage which requires sustainability practices to be applied to protect the country's economy and the present family businesses. According to a recent article in Gulf News, an estimated one trillion dollars in assets are going to be transferred to the UAE's next generation of family businesses [38]. Therefore, the second generation needs guidance on how to protect, develop and sustain this wealth for the generations ahead. 


\subsection{Family Business and Sustainability}

The World Commission on Environment and Development [39] defines business sustainability as meeting current needs without compromising the next generation's ability to meet its needs. Ward [40] has emphasized that each family business should have a plan for sustaining the business through the generations that will serve both the needs of the business and the needs of the family, thus setting both the family and the business onto the right path.

Researchers [41] believe that, to avoid complications, the family should agree to simplify ownership, governance and management structures by trimming the family tree at the appropriate time to achieve family harmony and longevity of business performance. However, this task is very difficult because it requires liquidity, which will affect the growth of the business [8]. Gameno Sandig, Labadie, Saris and Mayordomo [42] defined family complexity as "the number of family members and the type of relationships between them, and the number of family generations alive at a certain point in time". In addition, the degree of complexity is determined by the number of family members/generations that are involved in the business. Due to these complexities, the family business becomes complicated, often resulting in disagreements about leadership authorization and the business's strategic future. In this study, we argue not only that using the success factors at the right time will establish trust and loyalty among family members regardless of the number of generations present, but also guidelines and paths should be clearly laid down for the next generation to ensure further growth and development. It should also be determined what the family business successors should do to manage the business, and what the family business members personal share will be if they do not wish to participate in the business. Furthermore, depending on the business scale, it might not be affordable to have many family managers [36]; therefore, managers should be selected through succession planning and corporate governance, which is based on who can lead and improve the business. However, if some family members want to exit and liquidate their shares, the business's precise value and contractual exit terms should be known and agreed upon through professional external family advisors such as auditors, lawyers and bank professionals [41].

\subsection{Success Factors in Family Business Sustainability}

Several influencing factors linked to the survival of the family business have been reported in the literature [8].

\subsubsection{Succession Planning}

Succession planning is a structured approach to plan ahead for leadership positions in the family business; it can improve a potential leader's skills through experience and the assignment of appropriate tasks to individuals who will one day lead the family business [43]. If a business lacks proper planning, it may lead to business failure [44]. Succession is one of the most significant challenges experienced by family businesses $[45,46]$. The sudden death of the family business leader/founder will likely cause a dispute between the heirs and potential successors about power, authority and rights, which will create thorny estate issues [47].

Hence, prior studies highlighted the importance of succession planning to ensure the success of the generation transition and family business continuity [40,48-50]. To continue to prepare for the next generation, the succession plan must be initiated by the business's founder and continuously updated even after a successful business transition [44]. According to Sharma et al. [51], the succession process can be successful only in the presence of intentions to pursue succession, including the following: family commitment to the firm, a desire to keep the firm in the family and the ability of a trusted successor to assume control. 


\subsubsection{Strategic Planning}

Strategic planning is the process of developing a business strategy for creating internal and external operations to establish profitable growth [52]. Previous studies [53-55] have reported the important contribution of strategic planning to the success and long-term survival of family businesses. Strategic planning both establishes the business's scope and long-term goals and adopts resources and competencies in changing environments to achieve the required scope and goals [56]. Eddleston et al. [57] argue that family businesses in different generational management stages will have different needs with respect to both strategic planning and succession planning.

Strategic planning in family business helps in extending the business lifespan, and is different from strategic planning for non-family owned firms because it considers family issues and goals (Ward, 1988). Ward also explained the factors in strategic planning for family businesses; it starts with family commitment and goals to continue the business into the future. Therefore, the sub-criteria for strategic planning are family commitment on continuity, family issues and goals. Strategic planning is a key factor in ensuring the family business' long-term objectives and future goals [58].

\subsubsection{Corporate Governance}

For a multigenerational family firm to succeed and survive, it must have excellent management and governance [59]. Family firms depend on solid governance for the longevity of both the family and the firm [60]. Family businesses governance differs from nonfamily business governance for the following reasons: (1) the family has a long-term relationship with the business; (2) the family has its own cultural views and norms that are implemented in the business and perpetuated by the successive generations; and (3) the stakeholders and board members are genetically related to each other [61]. Hence, to secure their long-term interests, both the firm and the family need structured governance [62]. According to interviews with members of 59 family businesses by Rosenblatt, De Milk, Anderson, and Johnson [63] conflicts that arise in the family and business environment include the following: difficulty in separating family matters from business matters and vice versa, difficulty in making decisions, legacy and leadership.

These issues are solved through family business governance, which considers the thoughts of both the family and the business to embrace decision-making, planning and problem-solving structures for both the firm and the family system [55]. Hence, the sub-criteria explored in this research are decision-making structures and planning/problem solving structures.

Therefore, structured governance helps a family business make appropriate strategic decisions that influence the business's survival and long-term performance [64].

\subsubsection{Leadership}

Researchers and practitioners have been interested in the role of family members as leaders in family businesses [65]. Researchers acknowledge leadership as a major factor in a business's survival and success $[36,66,67]$. Leadership means guiding others to understand and accept what needs to be done and how it is to be done; it is the process of helping individuals equip themselves with knowledge to accomplish a unified objective [68]. In a family business, achieving competent family leadership through the generations is one of the greatest challenges to business continuity [69]. It is difficult to achieve competent family leadership without a willing successor or leadership skills that affect the business's continuity [70]. Therefore, the sub-criteria for leadership considered in this study are competent family member leadership and effective leadership skills.

In this regard, the founder or incumbent leader plays a vital role in teaching and training his or her successor so that he or she has the knowledge and skills required to lead and continue the business in the next generation [71,72].

Scholars note that to ensure the survival of a family firm across generations, a successful leadership transfer must occur when a leader retires [73]. 


\subsubsection{Family Business Values}

Family business values contribute to the longevity of the family business by configuring a common vision and creating a code of work $[59,74]$. Family business values are defined as clear and desirable goals for both family and business life. Given that there are often conflicts of interest between business and family goals, family business values should be well known and serve as a common ground between the business and the family to achieve their goals [75]. In a family business, various decision-making issues arise when family norms and business norms contradict one another [76]. According to Astrachan et al. [65], a firm can be called a family business only when the business and the family share values and assumptions. Family business values are key elements in sustaining the family firm; when both generations work together, values are successfully transferred to and embedded in the next generation [77].

Tapies and Moya [74] reported quality, honesty and hard work as the most important family values that highly contribute to the family firm longevity. Miller and Le Breton-Miller [78] identify value-driven employees as a fundamental condition for the continuity of family business. Therefore, the sub-criteria for family business values studied here are family norms and business norms.

\subsubsection{Family Capital}

Family capital contributes to a family business's achievements and long-term sustainability $[79,80]$. Family capital is the major source of the data and resources that influence and control the business, which is proven to increase family members' productivity [81]. Hoffman, Hoelscher, and Sorenson [82] state that family capital can improve family business performance and lead to a sustainable competitive advantage compared to non-family businesses in the market economy. According to Danes et al. [80], family capital represents the total resources of the owning family members and is divided into three components: human, social and financial capital. Sirmon and Hitt [83] describe the survivability of the family business as the combination of family human capital, social capital and financial capital. Family human capital is the knowledge, ability, energy and experience of family members regarding the business [79]. Limits to human capital is important which involves assigning family members in positions that suit their capabilities and experience rather than conferring a position of authority on a person merely for his family links [84]. Social capital is the importance of interactions and networking with individuals and corporations for the benefit of the current and long-term benefit of the family business [85]. Sorenson and Bierman [86] note that when family members maintain good social capital, they will expand the firm's human and financial capital. Therefore, together the three components of family capital are critical for the family firm's sustainability across generations. However, this study focuses on the sub-criteria of human and social capital. Financial capital will not be addressed with interviewees due to the sensitivity and confidentiality of the subject.

\subsubsection{Family Firm Advisors}

Family firm advising first emerged as a profession in the 1980s [87]. According to Craig and Moores [88], a family firm requires advisors to solve issues such as developing the family's personal, financial, succession and strategic plans; aligning family goals with business objectives; and conflict resolution. Previous research has demonstrated that family firm advisors are important resources for family businesses $[19,87,89,90]$. Additionally, family business advisors differ from non-family business advisors in their approach toward working with family, business and ownership by considering overlaps, content and complex emotions and using multidisciplinary strategies to solve personal and business conflicts [91,92]. Researchers such as Le Breton and Miller [93] suggested that family businesses are slower and more reluctant to professionalize than non-family businesses, particularly in terms of hiring external managers or seeking external advice and support. As observed by Strike [19], there are three types of family advisors: formal advisors, informal advisors, and family firm board advisors. Strike explains each type of advisor as follows: formal advisors hold either an 
external or internal position in the business and provide multiple professional support and advice services. Examples of formal advisors include accountants, lawyers, bankers, estate planners and family therapists. Informal advisors are not contractually engaged with the business and family and can be either external or internal. Examples of informal advisors include trust catalysts and mentors. Finally, family firm board advisors include family or nonfamily board members that influence decision-making and act as an advisory board for the firm's strategy, performance, succession and conflicts. Such advisors have the skills and expertise to contribute to the family business's long-term success [94]. Therefore, these three will be used as the sub-criteria for family firm advisors.

Consequently, family firm advisors are needed to provide guidance to solve challenges, resolve conflicts and ensure business stability.

In this study, seven criteria and fifteen sub-criteria that aid in the success and sustainability of multi-generation family businesses were gleaned from the literature. Past research findings are summarized and presented in Table 3.

Table 3. Criteria and sub-criteria of sustainability of multi-generation family businesses.

\begin{tabular}{|c|c|c|c|}
\hline & Criteria & Sub-Criteria & Reference \\
\hline 1 & Succession Planning & $\begin{array}{l}\text { Founder Initiative } \\
\text { Successor Ability/Desire }\end{array}$ & $\begin{array}{c}\text { Christensen (1953), Trow (1961), Ward (1987), Delmas and } \\
\text { Gergaud (2014), Writer (2017), Sharma et al. (2003a), } \\
\text { Sharma et al. (2003b) }\end{array}$ \\
\hline 2 & Strategic Planning & $\begin{array}{l}\text { Family Commitment on Continuity } \\
\text { Family Issues and Goals }\end{array}$ & $\begin{array}{l}\text { Astrachan and Kolenko (1994), Blumentritt (2006), Carlock } \\
\text { and Ward (2001), Ward (1988), Price Waterhouse Coopers } \\
\text { (PWC) (2016), Ward (1988) }\end{array}$ \\
\hline 3 & Corporate Governance & $\begin{array}{l}\text { Decision Making Structure } \\
\text { Planning/Problem } \\
\text { Solving Structure }\end{array}$ & $\begin{array}{l}\text { Lansberg (1999), Mustakallio, Autio, and Zahra (2002), } \\
\text { Pieper (2003), Aronoff (2004), Carlock and Ward (2001) }\end{array}$ \\
\hline 4 & Leadership & $\begin{array}{l}\text { Competent Family Member Leadership } \\
\text { Effective Leadership Skills }\end{array}$ & $\begin{array}{c}\text { Fiedler (1996), Gersick et al. (1997), } \\
\text { Hartel, Bozer, and Levizn (2009), Van der Westhuizen and } \\
\text { Garnett (2014), Le Breton-Miller, Miller, and Steier (2004), } \\
\text { Lansberg (1988) }\end{array}$ \\
\hline 5 & Family Business Values & $\begin{array}{l}\text { Family Norms } \\
\text { Business Norms }\end{array}$ & $\begin{array}{l}\text { Aronoff and Ward (2000), Erdem and Baser (2010), } \\
\text { Tapies and Moya (2012), Lansberg (1983), Koiranen (2002) }\end{array}$ \\
\hline 6 & Family Capital & $\begin{array}{l}\text { Human Capital } \\
\text { Social Capital }\end{array}$ & $\begin{array}{l}\text { Danes, Lee, Stafford, and Heck, (2008), Danes, Stafford, } \\
\text { Haynes, and Amarapurkar (2009), Stafford et al. (2010), } \\
\text { Sirmon and Hitt (2003), Danes et al. (2009) }\end{array}$ \\
\hline 7 & Family Firm Advisors & $\begin{array}{c}\text { Formal Advisors } \\
\text { Informal Advisors } \\
\text { Family Firm Board Advisors }\end{array}$ & $\begin{array}{l}\text { LaChapelle and Barnes (1998), Kaye and Hamilton (2004), } \\
\text { Astrachan and McMillan (2006), Strike (2012) }\end{array}$ \\
\hline
\end{tabular}

Source: Author's data.

\section{Methodology}

\subsection{Research Technique}

Saaty [31] introduced the Analytical Hierarchy Process (AHP) methodology for decision-making when dealing with complex decision problems. The AHP assists in arranging the main aspects of the issue into a hierarchical structure, in order to reduce the complex decisions to a series of simple evaluations and rankings, and then analyses the results to conclude a clear decision based on the rational weights of each aspect [95].

Recently, there has been a renewed interest in AHP as an emerging solution approach to complex real world and multi-criteria decision-making problems [96]. There are many examples proving the AHP as a powerful tool in achieving the main priority factor of an issue or a goal [97]. Over the past years, AHP has become one of the most widely used tools for decision support for researchers and decision makers [98,99].

The AHP methodology involves six steps as illustrated in Figure 1 [31]. The first step is defining the problem, i.e., how a multi-generation family business can be sustained in the UAE. The second step is developing the hierarchical structure of the problem as presented in Figure 2. The third step is constructing the pairwise comparison matrix of all the main criteria of each success factor. In this step, the interviewer fills the data according to the intensity of importance of each scale with its definition and explanation as listed in Table 4 [100]. The interviews were conducted with six large and six 
medium family businesses of different industries founded and established in the UAE. The fourth step is synthetisation, which is the process of calculating the relative priority of the alternatives in terms of the criterion. The exact mathematical process of calculating the priority weights involves the calculation of eigenvalues and eigenvectors. The eigenvalue is calculated by dividing each element in the pairwise comparison matrix by the sum of its corresponding column. Then, the eigenvector is calculated by averaging the row of eigenvalues calculated to conclude the priority weight of each criterion. The fifth step is to measure the consistency of the data obtained from the interviewers. To do so, first the consistency index (CI) is computed. Saaty [31] described consistency as follows:

$$
C I=\frac{\left(\lambda_{\max }-n\right)}{(n-1)}
$$

where $\lambda_{\max }$ is the maximum eigenvalue of the matrix of the priority ratios, and $\mathrm{n}$ is the number of factors. Second, we calculate the consistency ratio (CR). This is what we use to measure the consistency of the data obtained, and its formula is as follows:

$$
C R=\frac{C I}{R I}<0.1
$$

The random index is used to produce random indices for each size matrix. The values of RI are given in Table 5. For the matrix to be consistent, CR should be $\leq 0.1$ [31].

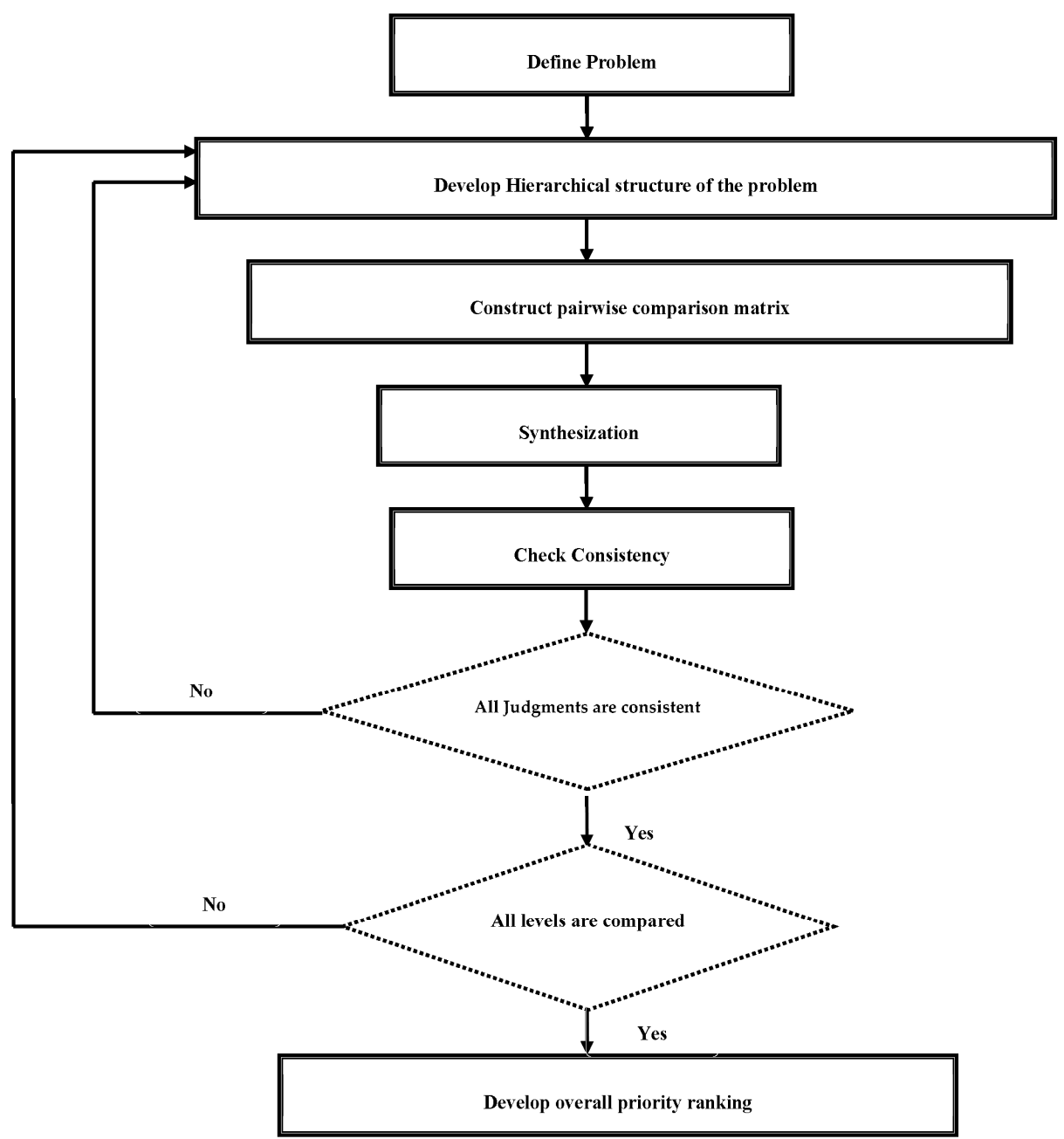

Figure 1. Outline of AHP method applied. (Source: Saaty (2012). 
Table 4. From 1 to 9 Scale of AHP preference.

\begin{tabular}{ccc}
\hline Intensity of Importance & Definition & Explanation \\
\hline 1 & Equal importance & Two criteria contribute equally to the objective \\
3 & Moderate importance & Judgement slightly favours one over another \\
5 & Strong importance & Judgement strongly favours one over another \\
6 & Very strong importance & A criterion is strongly favoured and its dominance is demonstrated in practice \\
9 & Absolute importance & Importance of one over another affirmed on the highest possible order \\
$2,4,6,8$ & Intermediate values & Used to represent compromise between the priorities listed above \\
\hline & \multicolumn{2}{c}{ Source: (Saaty, 1980). }
\end{tabular}

Table 5. Random Index.

\begin{tabular}{cccccccccccccccc}
\hline \multicolumn{11}{c}{ Order of the Matrix } \\
\hline & 1 & 2 & 3 & 4 & 5 & 6 & 7 & 8 & 9 & 10 & 11 & 12 & 13 & 14 & 15 \\
RI Value & 0 & 0 & 0.58 & 0.90 & 1.12 & 1.24 & 1.32 & 1.41 & 1.45 & 1.49 & 1.51 & 1.48 & 1.56 & 1.57 & 1.59 \\
\hline \multicolumn{11}{c}{ Source: (Saaty, 1980). }
\end{tabular}

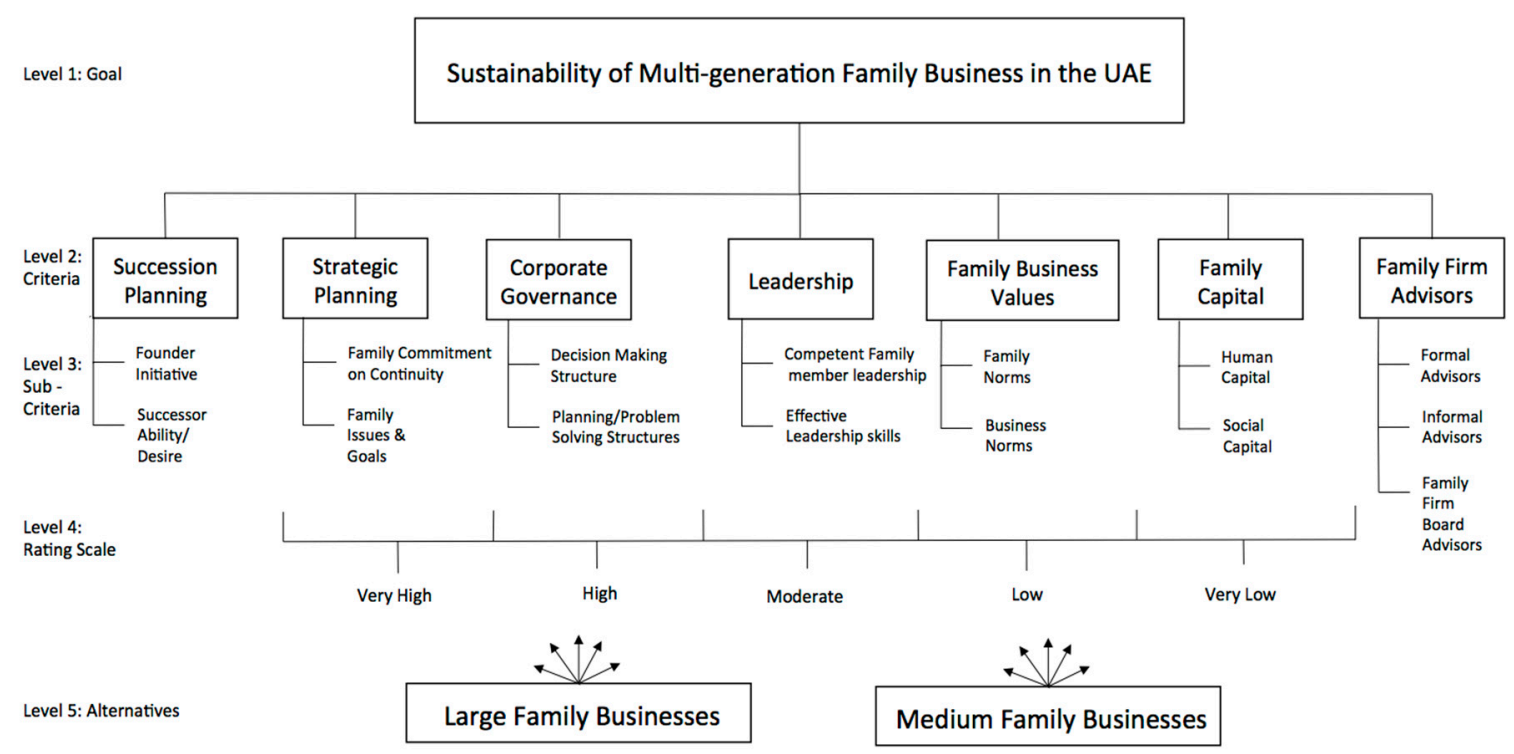

Figure 2. Proposed Research Model. Source: Author's data.

The AHP model used in this study is presented in Figure 2. The Top Level of the hierarchy states the main objective of the problem, which is the sustainability of the multi-generation family business in the UAE. Level two presents the main criteria of the model, which are the success factors stated in literature. Level three presents the sub-criteria of each factor. Each level of criteria is pairwise compared to its importance to the next higher level; this develops several matrices that compare each criterion in a given level to establish the highest factor importance to the hierarchy objective (level 1) [101]. Saaty [102] suggested a nine-point scale, as shown in Table 4, to define the pair-wise comparisons. Table 4 is the nine point-scale of AHP preferences, which is used by the individuals interviewed, to make the pairwise comparison rating of the criteria using Table 1 which shows the scale of the pairwise comparisons. For example, if an interviewer states that family values are strongly important to family capital, then the former is rated " 5 " and the latter is " $1 / 5$ " in this pairwise comparison. In this study, the interviewers are family members who hold a position in the family business. The large and medium family businesses are the alternatives considered to achieve the goal; they are placed in level 4 of the AHP model. 


\subsection{Data Collection and Interview Procedure}

The researcher first started the investigation by searching for family businesses in the list of companies registered under Abu Dhabi and Dubai Chambers of Commerce This list provides details of the companies such as, company name, city, telephone number, activity, and website. The company website provides insight on the nature of the business, whether the business is a FB's and, if it is, its size. The website also shows the company history and the organisational charts which provide information about the age of the company and its management.

Based on this information, twenty family business companies were selected randomly for their family member managers to be interviewed. A letter of inquiry that included a brief description of the study and the work intended [103] was circulated officially to these family businesses addressing the family members. The letter was sent to the companies by email and its hard copy to their head offices.

Of these twenty companies, twelve indicated their interest in being part of this research. Six of these were large sized family businesses and the other six were medium sized family businesses. Small family businesses were not considered in this research as most of the sustainability factors obtained from literature do not apply to small businesses because they lack an adequate number of human resources. Therefore, scheduled appointments for interviews took around one month to complete, and was conducted by a single interviewer. Interviews were all taken in the respondent companies' head offices. All interviews had the same set of questions, derived from Figure 2, following the AHP preference scale. Interviews were necessary in this study for the following reasons:

1. To ensure that the respondent is the right person filling the AHP preference scale.

2. For the interviewer to understand how the business is running and how it is led.

3. For the interviewer to evaluate the family members' business knowledge and their preparation for future generations.

The nature and summary of the basic information on the large and medium sized companies is presented in Tables 6 and 7. Past research published on AHP methodology [97,98], affirm that the sample of data collected is enough to proceed with the methodology [102]. 
Table 6. Summary of basic information of large sized family companies.

\begin{tabular}{|c|c|c|c|c|c|c|}
\hline & L1 & L2 & L3 & L4 & L5 & L6 \\
\hline Industry & $\begin{array}{c}\text { Diversified (e.g., Retail, Real } \\
\text { Estate, Construction, Oil Field } \\
\text { Services, etc.) }\end{array}$ & $\begin{array}{l}\text { Diversified (e.g., Automotive, } \\
\text { Oil and Gas, Contracting, } \\
\text { Commercial, Marine } \\
\text { Engineering, etc.) }\end{array}$ & Construction & $\begin{array}{l}\text { Retail of large Swiss } \\
\text { Watches Brand }\end{array}$ & $\begin{array}{c}\text { Manufacturing } \\
\text { (Ready Mix Concrete) }\end{array}$ & $\begin{array}{l}\text { Diversified (e.g., Hospitality, } \\
\text { Real Estate, Automotive, } \\
\text { Travel, and Future Projects) }\end{array}$ \\
\hline Year established & 1977 & 1979 & 1970 & 1950 & 1972 & 1962 \\
\hline Ownership & $100 \%$ & $100 \%$ & $100 \%$ & $100 \%$ & $100 \%$ & $100 \%$ \\
\hline Managing generation & First/Second & Second & First/Second & Second/Third & First/Second & $\begin{array}{l}\text { Family Supervisory board First } \\
\text { and Second }\end{array}$ \\
\hline $\begin{array}{l}\text { No. of Family members } \\
\text { In the business }\end{array}$ & 7 & 8 & 3 & 9 & 3 & 9 \\
\hline Interviewee & $\begin{array}{c}\text { Son } \\
\text { (Chief Executive Officer) }\end{array}$ & $\begin{array}{c}\text { Son } \\
\text { (Managing Director) } \\
\end{array}$ & $\begin{array}{c}\text { Daughter } \\
\text { (Projects Director) } \\
\end{array}$ & $\begin{array}{c}\text { Son } \\
\text { (Chairman) }\end{array}$ & $\begin{array}{c}\text { Father } \\
\text { (Chairman) }\end{array}$ & $\begin{array}{c}\text { Second } \\
\text { (Supervisory Board Member) }\end{array}$ \\
\hline Strategic Decision & $\begin{array}{l}\text { Father } \\
\text { (Chairman) }\end{array}$ & $\begin{array}{l}\text { Family council, board of } \\
\text { directors }\end{array}$ & $\begin{array}{c}\text { Father } \\
\text { (Chairman) }\end{array}$ & $\begin{array}{l}\text { Family council, board } \\
\text { of directors }\end{array}$ & $\begin{array}{l}\text { Father } \\
\text { (Chairman) }\end{array}$ & Family Supervisory board \\
\hline
\end{tabular}

Table 7. Summary of basic information of medium sized family companies.

\begin{tabular}{|c|c|c|c|c|c|c|}
\hline & M1 & M2 & M3 & M4 & M5 & M6 \\
\hline Industry & Construction & $\begin{array}{c}\text { Manufacturing } \\
\text { (Aluminium and Carpentry) }\end{array}$ & Consultancy & $\begin{array}{c}\text { Piling } \\
\text { (Construction) }\end{array}$ & Construction & Dental \\
\hline Year established & 1994 & 1996 & 1981 & 1989 & 1998 & 2000 \\
\hline Ownership & $100 \%$ & $100 \%$ & $100 \%$ & $100 \%$ & $100 \%$ & $100 \%$ \\
\hline Manging generation & First/Second & First/Second & First/Second & First & First & First (Two founder brothers) \\
\hline $\begin{array}{l}\text { No. of family members } \\
\text { in the business }\end{array}$ & 3 & 2 & 2 & 2 & 2 & 2 \\
\hline Interviewee & $\begin{array}{c}\text { Father } \\
\text { (Chairman) }\end{array}$ & $\begin{array}{c}\text { Son } \\
\text { (General Manager) }\end{array}$ & $\begin{array}{c}\text { Daughter } \\
\text { (Design Manager) }\end{array}$ & $\begin{array}{c}\text { Father } \\
\text { (Managing Director) }\end{array}$ & $\begin{array}{c}\text { Father } \\
\text { (Chairman) }\end{array}$ & $\begin{array}{l}\text { One founder brother } \\
\text { (Head Orthodontist) }\end{array}$ \\
\hline Strategic Decision & $\begin{array}{l}\text { Father } \\
\text { (Chairman) }\end{array}$ & $\begin{array}{l}\text { Father } \\
\text { (Chairman) }\end{array}$ & $\begin{array}{l}\text { Father } \\
\text { (Chairman) }\end{array}$ & $\begin{array}{c}\text { Father } \\
\text { (Managing Director) }\end{array}$ & $\begin{array}{l}\text { Father } \\
\text { (Chairman) }\end{array}$ & $\begin{array}{l}\text { Two founder brothers } \\
\text { (Head Orthodontist and Head of } \\
\text { dental surgery) }\end{array}$ \\
\hline
\end{tabular}




\subsection{Results}

\subsubsection{Pairwise Comparison for Main-Criteria}

Tables 8 and 9 represent the geometric means of pair-wise comparisons for the seven main criteria to achieve the goal in the research model for medium and large sized family businesses. The step thereafter was to define the relative priorities of the main criteria (the final column under the headline W (Priority)) by calculating the "Priority Vectors". Saaty [102]. established a "Consistency Principle" for computing priority vectors. This consistency principle is aik = aij. ajk, and the following argument for using special case of the consistency matrix established by elements $a i k=w i / w j$, where wi and wj are the components of the priority weight vector indicating to criteria $i$ and $j$.

Table 8. Medium Family Business-Pairwise comparison.

\begin{tabular}{|c|c|c|c|c|c|c|c|c|}
\hline \multicolumn{9}{|c|}{ Medium Family Business-Pairwise Comparison } \\
\hline & SP & STP & CG & LED & $\mathrm{FV}$ & $\mathrm{FC}$ & FA & W (Priority) \\
\hline SP & 1.00 & 3.67 & 3.67 & 0.15 & 0.23 & 0.20 & 4.33 & 0.105 \\
\hline STP & 0.27 & 1.00 & 3.33 & 0.17 & 0.25 & 0.20 & 5.00 & 0.077 \\
\hline CG & 0.27 & 0.30 & 1.00 & 0.17 & 0.22 & 0.22 & 2.67 & 0.045 \\
\hline LED & 6.61 & 5.94 & 5.76 & 1.00 & 2.33 & 3.00 & 6.67 & 0.368 \\
\hline FV & 4.26 & 0.30 & 4.54 & 0.43 & 1.00 & 1.89 & 5.33 & 0.185 \\
\hline FC & 5.05 & 3.97 & 4.54 & 0.33 & 0.53 & 1.00 & 6.33 & 0.192 \\
\hline FA & 0.23 & 0.20 & 0.38 & 0.15 & 0.19 & 0.16 & 1.00 & 0.029 \\
\hline Sum & 17.69 & 15.38 & 23.22 & 2.41 & 4.76 & 6.66 & 31.33 & $\begin{array}{c}1.000 \\
\text { CR } \\
0.09\end{array}$ \\
\hline
\end{tabular}

Table 9. Large Family Business-Pairwise Comparison.

\begin{tabular}{ccccccccc}
\hline \multicolumn{8}{c}{ Large Family Business-Pairwise Comparison } \\
\hline & SP & STP & CG & LED & FV & FC & FA & W (Priority) \\
SP & 1.00 & 0.98 & 0.72 & 3.67 & 5.33 & 4.56 & 5.00 & 0.230 \\
STP & 1.02 & 1.00 & 2.78 & 3.67 & 5.67 & 4.33 & 4.67 & 0.284 \\
CG & 1.38 & 0.36 & 1.00 & 4.67 & 6.00 & 3.89 & 3.67 & 0.223 \\
LED & 0.27 & 0.27 & 0.21 & 1.00 & 4.33 & 4.00 & 3.67 & 0.116 \\
FV & 0.19 & 0.36 & 0.17 & 0.23 & 1.00 & 0.49 & 0.31 & 0.039 \\
FC & 0.22 & 0.18 & 0.26 & 0.25 & 2.05 & 1.00 & 0.85 & 0.049 \\
FA & 0.20 & 0.21 & 0.27 & 0.27 & 3.20 & 1.17 & 1.00 & 0.058 \\
Sum & 4.28 & 3.36 & 5.41 & 13.75 & 27.59 & 19.44 & 19.16 & 1.000 \\
\hline
\end{tabular}

The pairwise comparison for medium sized family businesses are presented in Table 8 and Figure 3. The consistency factor is 0.09 , being less than 0.1 , shows that the comparison is acceptable. The results for medium sized family business showed leadership as the highest priority factor equal to 0.368. However, the lowest priority factor is family firm advisors equal to 0.029. Table 9 and Figure 4 present the pairwise comparison for large sized family businesses. The table shows consistency, as the factor is 0.093 , which is less than 0.1. The highest priority factor for large family businesses is strategic planning having weight equal to 0.284 . However, the lowest priority factor is family values having the weight equal to 0.039 . Figures 3 and 4 show the success factors ranging from the highest to the lowest priorities in the current medium and large UAE family businesses. 


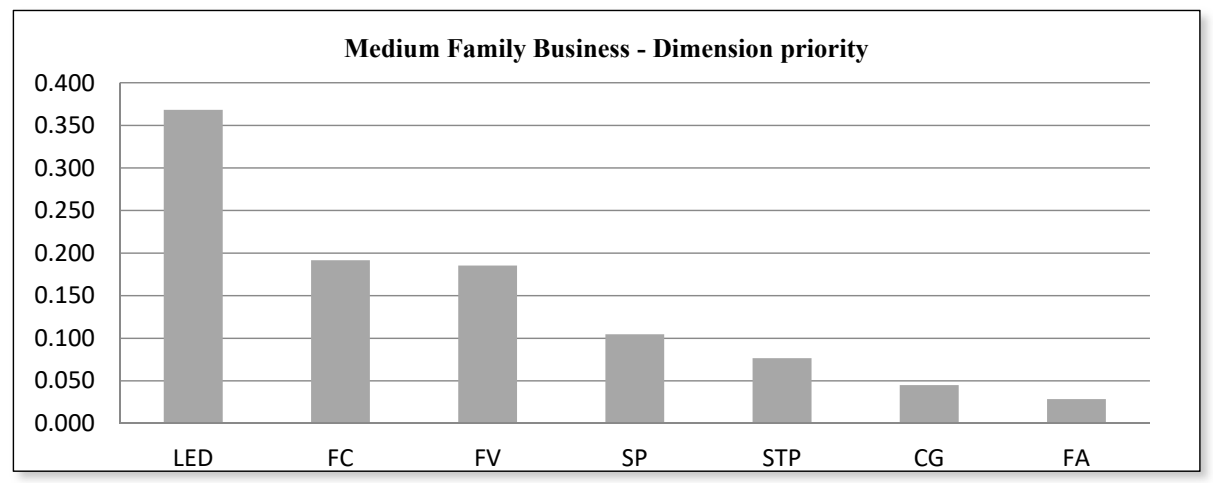

Figure 3. Medium Family Business-Dimension Priority.

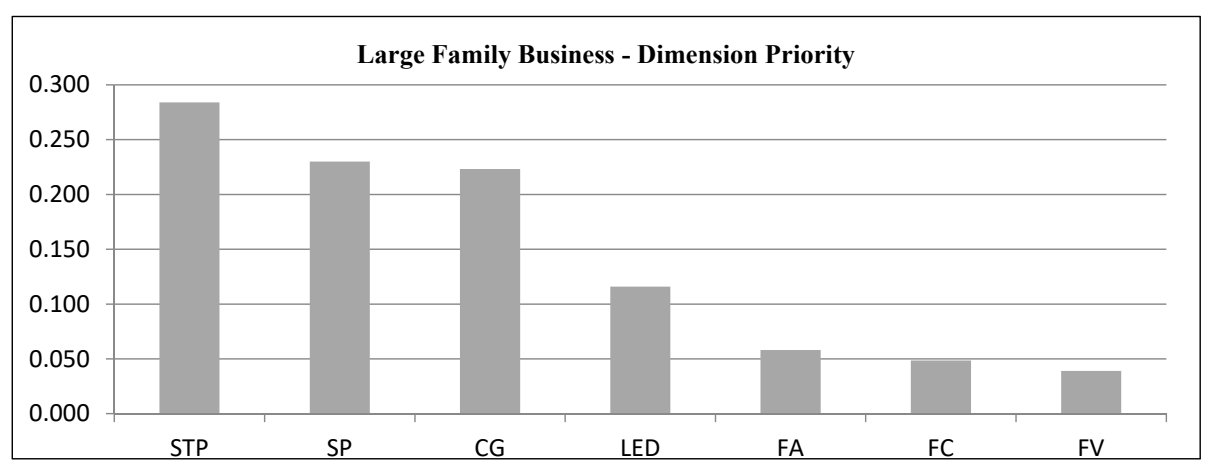

Figure 4. Large Family Business-Dimension Priority.

\subsubsection{Pairwise Comparison for Sub-Criteria}

The results of the calculations of the priority of each sub-factor in both medium and large family businesses are presented in Tables 10-16.

Table 10. Pairwise Comparison for Succession Planning Sub-Criteria.

\begin{tabular}{ccccccc}
\hline & \multicolumn{3}{c}{ Large Family Business } & \multicolumn{3}{c}{ Medium Family Business } \\
\cline { 2 - 7 } & $\begin{array}{c}\text { Founder } \\
\text { Initiative }\end{array}$ & $\begin{array}{c}\text { Successor } \\
\text { Ability/Desire }\end{array}$ & W (Priority) & $\begin{array}{c}\text { Founder } \\
\text { Initiative }\end{array}$ & $\begin{array}{c}\text { Successor } \\
\text { Ability/Desire }\end{array}$ & W (Priority) \\
\hline Founder Initiative & 1.0 & 2.72 & 0.731 & 1.0 & 5.22 & 0.839 \\
Successor Ability/Desire & 0.37 & 1.0 & 0.269 & 0.19 & 1.0 & 0.161 \\
Sum & 1.37 & 3.72 & 1.0 & 1.19 & 6.22 & 1.0 \\
\hline
\end{tabular}

The pairwise comparison of the demographic characteristics sub-criteria of succession planning for both large and medium family businesses are represented in Table 10. Founder initiative was found to be the most important sub-criterion for both large (priority weight $=0.731$ ) and medium family businesses (priority weight $=0.839$ ).

Table 11. Pairwise Comparison for Strategic Planning Sub-Criteria.

\begin{tabular}{cccccc}
\hline & \multicolumn{3}{c}{ Large Family Business } & \multicolumn{2}{c}{ Medium Family Business } \\
\cline { 2 - 5 } & $\begin{array}{c}\text { Family Commitment } \\
\text { on Continuity }\end{array}$ & $\begin{array}{c}\text { Family Issues } \\
\text { and Goals }\end{array}$ & W (Priority) & $\begin{array}{c}\text { Family Commitment } \\
\text { on Continuity }\end{array}$ & $\begin{array}{c}\text { Family Issues } \\
\text { and Goals }\end{array}$ \\
\hline $\begin{array}{c}\text { Family Commitment } \\
\text { on Continuity }\end{array}$ & 1.0 & 6.0 & 0.857 & 1.0 & 5.53 \\
\hline $\begin{array}{c}\text { Family Issues and } \\
\text { Goals }\end{array}$ & 0.17 & 1.0 & 0.143 & 0.18 & 0.847 \\
\hline Sum & 1.17 & 7.0 & 1.0 & 1.18 & 0.153 \\
\hline
\end{tabular}


Table 11 shows the pairwise comparison of the demographic characteristics sub-criteria of strategic planning for both large and medium family businesses. Family commitment to continuity was found to be the most important sub-criterion for both at 0.857 priority weight for large and 0.847 priority weight for medium FBs.

Table 12. Pairwise Comparison for Corporate Governance Sub-Criteria.

\begin{tabular}{|c|c|c|c|c|c|c|}
\hline & \multicolumn{3}{|c|}{ Large Family Business } & \multicolumn{3}{|c|}{ Medium Family Business } \\
\hline & $\begin{array}{c}\text { Decision Making } \\
\text { Structure }\end{array}$ & $\begin{array}{l}\text { Planning/Problem } \\
\text { Solving Structure }\end{array}$ & W (Priority) & $\begin{array}{c}\text { Decision Making } \\
\text { Structure }\end{array}$ & $\begin{array}{c}\text { Planning/Problem } \\
\text { Solving Structure }\end{array}$ & W (Priority) \\
\hline $\begin{array}{l}\text { Decision Making } \\
\text { Structure }\end{array}$ & 1.0 & 3.2 & 0.762 & 1.0 & 1.76 & 0.637 \\
\hline $\begin{array}{l}\text { Planning/Problem } \\
\text { Solving Structure }\end{array}$ & 0.31 & 1.0 & 0.238 & 0.57 & 1.0 & 0.363 \\
\hline Sum & 1.31 & 4.2 & 1.0 & 1.57 & 2.76 & 1.0 \\
\hline
\end{tabular}

Table 12 showed the pairwise comparison of the demographic characteristics sub-criteria of corporate governance for both large and medium family businesses. Decision-making structure was found to be the more important sub-criterion for both at 0.762 priority weight for large and 0.637 priority weight for medium sized companies.

Table 13. Pairwise Comparison for Leadership Sub-Criteria.

\begin{tabular}{|c|c|c|c|c|c|c|}
\hline & \multicolumn{3}{|c|}{ Large Family Business } & \multicolumn{3}{|c|}{ Medium Family Business } \\
\hline & $\begin{array}{l}\text { Competent Family } \\
\text { Member Leadership }\end{array}$ & $\begin{array}{c}\text { Effective Leadership } \\
\text { Skills }\end{array}$ & W (Priority) & $\begin{array}{l}\text { Competent Family } \\
\text { Member Leadership }\end{array}$ & $\begin{array}{c}\text { Effective Leadership } \\
\text { Skills }\end{array}$ & W (Priority) \\
\hline $\begin{array}{l}\text { Competent Family } \\
\text { Member Leadership }\end{array}$ & 1.0 & 0.96 & 0.489 & 1.0 & 2.75 & 0.733 \\
\hline $\begin{array}{l}\text { Effective Leadership } \\
\text { Skills }\end{array}$ & 1.05 & 1.0 & 0.511 & 0.36 & 1.0 & 0.267 \\
\hline
\end{tabular}

Table 13 shows the pairwise comparison of the demographic characteristics sub-criteria of leadership for both large and medium family businesses. Effective leadership skills sub-criterion is found to have a higher priority of 0.511 for large companies and competent family member leadership sub-criterion to have a higher priority of 0.733 for medium companies.

Table 14. Pairwise Comparison for Family Business Values Sub-Criteria.

\begin{tabular}{ccccccc}
\hline & \multicolumn{3}{c}{ Large Family Business } & \multicolumn{2}{c}{ Medium Family Business } \\
\cline { 2 - 6 } & Family Norms & Business Norms & W (Priority) & Family Norms & Business Norms & W (Priority) \\
\hline Family Norms & 1.0 & 4.56 & 0.774 & 1.0 & 0.95 & 0.486 \\
Business Norms & 0.22 & 1.0 & 0.180 & 1.06 & 1.0 & 0.514 \\
Sum & 1.22 & 5.56 & 1.0 & 2.06 & 1.95 & 1.0 \\
\hline
\end{tabular}

Table 14 shows the pairwise comparison of the demographic characteristics sub-criteria of family business values for both large and medium family businesses. Family norms sub-criterion is found to have higher priority of 0.774 for large companies and business norms sub-criterion has a higher priority of 0.514 for medium companies.

Table 15. Pairwise Comparison for Family Capital Sub-Criteria.

\begin{tabular}{|c|c|c|c|c|c|c|}
\hline & \multicolumn{3}{|c|}{ Large Family Business } & \multicolumn{3}{|c|}{ Medium Family Business } \\
\hline & Human Capital & Social Capital & W (Priority) & Human Capital & Social Capital & W (Priority) \\
\hline Human Capital & 1.0 & 2.7 & 0.731 & 1.0 & 2.2 & 0.688 \\
\hline Social Capital & 0.37 & 1.0 & 0.269 & 0.45 & 1.0 & 0.313 \\
\hline
\end{tabular}


Table 15 shows the pairwise comparison of the demographic characteristics sub-criteria of family capital for both large and medium family businesses. Human capital is seen to be the more important sub criteria for both at 0.731 for large companies and 0.688 for medium companies. Consistency for only two or fewer sub-criteria is not tested, as both sub criteria are equally validated and CR is zero [102]; therefore, consistency test for Tables 10-15 is not required.

Table 16. Pairwise Comparison for Family Firm Advisors Sub-Criteria.

\begin{tabular}{|c|c|c|c|c|c|c|c|c|}
\hline & \multicolumn{4}{|c|}{ Large Family Business } & \multicolumn{4}{|c|}{ Medium Family Business } \\
\hline & Formal Advisors & $\begin{array}{l}\text { Informal } \\
\text { Advisors }\end{array}$ & $\begin{array}{c}\text { Family Board } \\
\text { Advisors }\end{array}$ & $\begin{array}{c}\text { W } \\
\text { (Priority) }\end{array}$ & $\begin{array}{c}\text { Formal } \\
\text { Advisors }\end{array}$ & $\begin{array}{l}\text { Informal } \\
\text { Advisors }\end{array}$ & $\begin{array}{c}\text { Family Board } \\
\text { Advisors }\end{array}$ & W (Priority) \\
\hline $\begin{array}{l}\text { Formal } \\
\text { Advisors }\end{array}$ & 1.0 & 4.22 & 3.67 & 0.648 & 1.0 & 5.53 & 6.33 & 0.743 \\
\hline $\begin{array}{l}\text { Informal } \\
\text { Advisors }\end{array}$ & 0.24 & 1.0 & 2.44 & 0.227 & 0.18 & 1.0 & 1.15 & 0.134 \\
\hline $\begin{array}{c}\text { Family } \\
\text { Board } \\
\text { Advisors }\end{array}$ & 0.24 & 0.41 & 1.0 & 0.125 & 0.18 & 0.87 & 1.0 & 0.123 \\
\hline Sum & 1.47 & 5.63 & 7.11 & 1.0 & 1.36 & 7.41 & 1.0 & 1.0 \\
\hline CR & \multicolumn{4}{|c|}{$\mathrm{CR}=0.05<0.1$} & \multicolumn{4}{|c|}{$\mathrm{CR}=0.04<0.1$} \\
\hline
\end{tabular}

Table 16 shows the pairwise comparison of the demographic characteristics sub-criteria of family firm advisors for both large and medium family businesses. Family firm advisor's sub-criteria has three sub factors; therefore, a consistency test was conducted for them. For large family businesses, $\mathrm{CR}$ is equal to 0.05 , which is less than 0.1 ; therefore, it is consistent. Similarly, for medium family businesses, CR is equal to 0.04 , which is less than 0.1 ; therefore, it is also consistent. On computing that, formal advisors is the more important sub-criterion for both at 0.648 priority weight for large companies and 0.743 for medium enterprises.

\subsection{Computing Alternatives Global Weights}

The last step in the analysis is to compare the global priorities of each large and medium sized family business. Global weights are the multiplication of the derived sub-criteria priorities to the criterion [101]. The global weight is simply normalization of the linear combination achieved by multiplying the weight of the sub-criteria with the weight of the main criteria. For example, in large family businesses, the sub-criterion "family commitment to continuity" is calculated by multiplying its weight (0.857) with its main criterion "strategic planning" weight (0.284) resulting in a global weight equal to 0.245 , as shown in Figure 5. It concludes the final result of all the priorities of the criterion multiplied by the sub-criterion priorities to establish the global weights of all sub-criteria. The sub-criteria are the 15 items of the seven criteria presented from highest to lowest in Figure 5 for large family businesses, and in Figure 6 for medium sized family businesses.

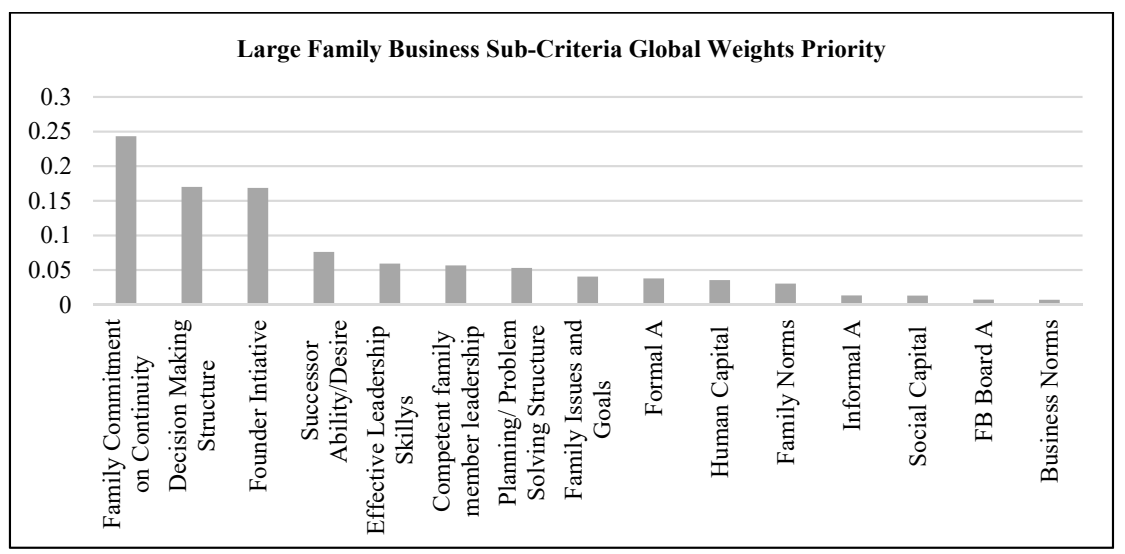

Figure 5. Large Family Business—Sub Criteria Global Weight Priority. 


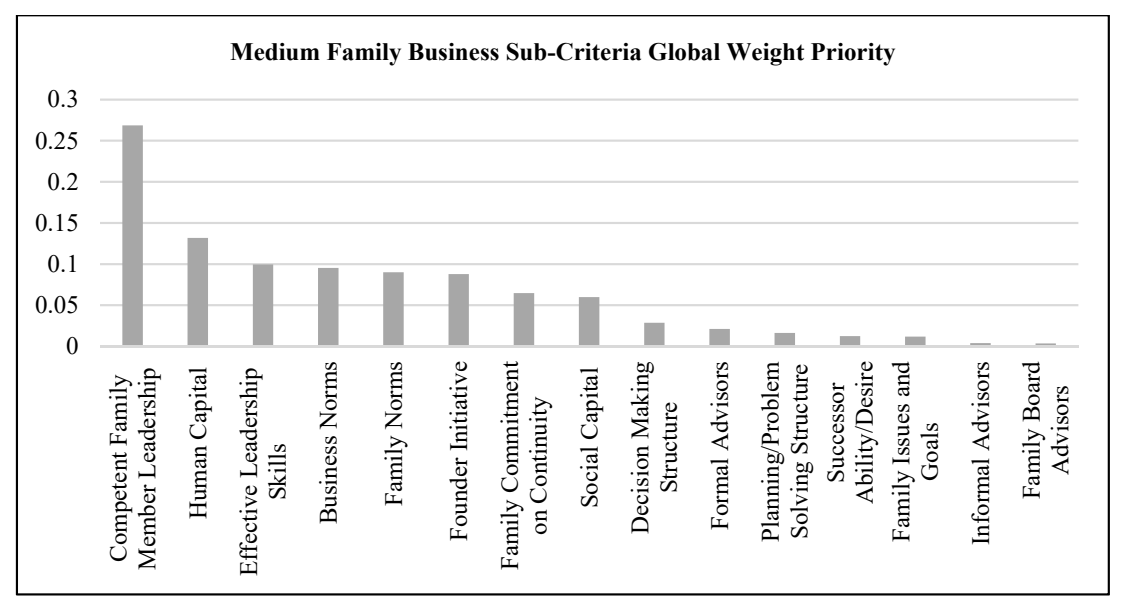

Figure 6. Medium Family Business—Sub Criteria Global Weight Priority.

\section{Discussion}

This paper is designed to prioritize and compare the factors of sustainability in large and medium sized family businesses in the United Arab Emirates. Based on the AHP empirical study of twelve large and medium sized family businesses, we can evaluate the current presence and significance of each sustainability factor critical to both medium and large family businesses. We can also compare different sized family businesses with each other in terms of the sustainability factors. First, succession planning is highly considered by the leading members of the large sized family businesses. They are very much aware of this process and it is implemented with great care. It is rated the second highest factor which shows that they plan ahead for the succession of leadership positions in their organizations. However, in the medium sized family businesses, this idea is not completely implemented, as it shows to be of median factor significance, which is a threat to the sustainability of the family business. Hence, more importance should be given to succession planning, as noted by Neubauer [104]. If succession does not occur or is postponed for too long, there can be major negative consequences for the family business, leading to its closure. Second, strategic planning in the large family businesses is their highest priority factor, which implies that the family business leaders are always working on improving their strategic plan to meet their future goals. However, in the case of medium sized family businesses, this is not their main concern as this factor is third in rank from the bottom, which implies that they are only planning for short term profits and not planning ahead for their future growth. The medium sized family businesses need to give this factor more attention, because some family businesses need a strategic plan just to survive from the current generation to the next [105]. Third, corporate governance in large family businesses is rated as the third highest in significance although it is noted previously in literature that structured governance is required to make proper strategic decisions that direct the strategic business plan [64]. Therefore, large family businesses should give greater importance to business governance to be able to make appropriate strategic planning. In the medium family businesses, corporate governance is rated just before the last, which puts the business at risk, as it implies that the business is dependent exclusively on the family business leader. Once the leader is gone, the business would fail due to the lack of improper decision-making. Therefore, they should work on improving their family businesses governance. This allows family members to discuss and be informed of the business vision, mission and values, its major developments, accomplishments, challenges and strategic directions, its rules and decisions regarding dividends, employment and benefits, the formal communication channels to share ideas and discuss issues as well as the business's structure, processes and policies [106]. Fourth, leadership in large family businesses is rated moderately, which explains that more than one family business leader is running the business and the business is structured for decisions to be taken as a team. This shows that the family members have a good understanding among 
one another and that the business has a structured corporate governance. This team based decision by family owned businesses is a reflection of their being collectivistic in nature as recommended by Hofstede [107]. In the medium sized family business, leadership is rated as having the highest significance, which shows that the whole business is directed and dependent on the family business leader. This again puts the business at risk. In the absence of the leader, the business would lack the necessary leadership or the necessary skills to run the business. Therefore, they should focus more on succession planning and motivate their successors to acquire the necessary experience and knowledge and learn the skills for leading the business when it is required, as noted previously in literature by Starke and Mischke [72]. Fifth, family values are seen to be the lowest significant factor in large family businesses which implies that most of the family values are weak and not well defined. This could cause conflicts between the decisions taken by the successors of the family and the business. Hence, they should implement the family business values, as defined by Tàpies and Moya [74]: values related to family cohesion, such as loyalty, honesty and respect; values related to a firm's sustainability, such as excellence, profitability and hard work; and values that help transmit core values such as social responsibility, accountability and transparency. In medium sized family businesses, family values are rated at third highest significance which shows that values are well defined by the founder and the successors work together abiding by known family business values. Sixth, family capital is rated before the last in large family businesses, which shows that the business resources and social network are already well established, and family members do not invest much time in building their human, social and financial capital. This is not desirable for the business as it limits the business growth by restricting the building of new relations and expanding of the financial capital. It is also very important to allocate the business resources and transfer the social network to the successors in order to sustain the family business. In medium sized family businesses, family capital is of the second highest significance, which indicates that the family members work on expanding their social, human and financial capital. This is very advantageous both for the business and the family. Lastly, family firm advisors are rated third from the last in large family businesses, which implies that the family members take consulting advisors' help in some aspects of the family and the business. However, in medium sized family businesses, it is rated as the lowest factor, which indicates that the family members barely use any outside advisors. This is harmful for the growth and survival of the business. As emphasized by Reay, Pearson, and Dyer [94], external advisors have the skills and expertise to contribute to the family business's long-term success.

In large family businesses, the highest global weight sub-criterion is family commitment to continuity and the lowest global weight sub-criterion is business norms. In medium family businesses, the highest global weight sub-criterion is competent family member leadership and the lowest global weight sub-criterion is family board advisors.

\section{Conclusions}

The role of different success factors in the sustainability of multi-generation family businesses has been proven in the previous family business research [8]. However, there is a lack of research that highlights the importance of the combined implementation of all success factors for the sustainability of multi-generation family business, especially in the context of developing countries such as the UAE.

This research is an empirical study of multi-generation family firms in the UAE. From previous literature, this paper combined the major success factors that have impacted the family firm's sustainability in well-developed countries and investigated each factor in the current large and medium multi-generation family businesses in the UAE. A questionnaire was formatted on a nine-point scale based on the success factors. The data were collected from six multi-generation family businesses competing in different industries of the UAE market. Consistency tests were performed on all the pairwise comparisons to observe the consistency of the data collected. These tests concluded the consistency of all the pair-wise comparisons performed. 
The major findings of this study are that large family businesses in the UAE are aware of transition failure and have long-term planning for their future generations in place; however, they need to give more importance to abiding by family values and building the family capital. On the other hand, medium sized family businesses in the UAE are less aware of transition failure and have less long-term planning; they are more concerned with short-term returns. Therefore, they need to create and give more importance to succession planning, strategic planning and corporate governance to ensure their business longevity. The study adequately answers its research question by explaining in detail the factors that are important for the long-term sustainability of both large and medium sized family businesses in the UAE. The findings are in alignment with those of Eddleston et al. [57] who emphasized the importance of succession planning and strategic planning in family businesses. The comparison between the highest and lowest success factors of medium and large family businesses is clearly explained in the discussion. This study aims to open the eyes of the large and medium sized family businesses of the UAE to start caring more about implementing each success factor with greater zeal and commitment to ensure the longevity and sustainability of their family businesses.

\subsection{Theoretical Implications}

This study has combined all the major factors that contribute to family business sustainability and long-term growth. Therefore, it has implications for theory as it has added a new model that can be used for future research. Pursuant to previous family business studies, it has shown the comparison between medium and large sized family businesses in their preparation for the future in the context of the UAE. Future research can use the model to study the significance of these factors in individual countries and determine the factors that are of the highest importance to family business sustainability in their country.

\subsection{Practical Implications}

This study is of great contribution to family managers, family shareholders, nonfamily business managers, policy makers and government officials, as well as to academics who want to learn about the factors that can successfully lead family firms in the future. The study results provide an insight into the practices that the family owned businesses must adopt to survive and succeed across family business life cycles. This study has implications for family business owners seeking to ensure the continuity of their business for their family and for their country's economy.

\subsection{Limitations}

The study is limited to family businesses in the UAE with family members working in the business, who are in the first to second and second to third generation; thus, the main criteria can apply, be valid and have reliability. The study is also limited to the small sample size and to the small number of criteria in research to assess business success and sustainability. In addition, to conduct such interviews with family members regarding their business succession is a very sensitive topic; hence, it is hard to get the best feedback. The interviewer should read the respondents' reactions and emotions towards the questions and analyse accordingly. Furthermore, future research can use this model for quantitative methodology and create hypotheses showing the significance of each success factor to the goal. In addition, it can be used to create qualitative interview questions to test and evaluate the implementation of the success factors in the context of other countries. Furthermore, future research can test the significance of these success factors by applying other advanced statistical methods on a bigger sample of large and medium family businesses.

Acknowledgments: The authors wish to thank the Editor(s), and three anonymous reviewers for their constructive comments.

Author Contributions: Mohammed Oudah and Fauzia Jabeen conceived and designed the experiments; Mohammed performed the experiments; Mohammed and Fauzia analyzed the data; Christopher Dixon 
contributed in the literature; Mohammed wrote the paper, and Fauzia guided Mohammed in the overall manuscript preparation.

Conflicts of Interest: The authors declare no conflict of interest.

\section{References}

1. Zahra, A.; Sharma, P. Family Business Research: A strategic Reflection. Fam. Bus. Rev. 2004, 15, 331-346. [CrossRef]

2. Schulze, W.S.; Gedajlovic, E.R. Whither family business? J. Manag. Stud. 2010, 47, 191-204. [CrossRef]

3. Astrachan, J.H. Commentary on the special issue: The emergence of a field. J. Bus. Ventur. 2003, 18, 567-573. [CrossRef]

4. Poza, E.J. Family Business 3E; South-Western Cengage Learning: Mason, OH, USA, 2010.

5. El Agamy, F.; Schreiber, C. Good Governance in Family Firms: Five Case Studies from the Middle East; Tharwat Family Business Forum and Pearl Initiative: Singapore, 2014.

6. Davis, J. The Family Business in the World Economy; (H. B. School, Interviewer); Hathaway Brown School: Shaker Heights, OH, USA, 2014.

7. Making, S.G. Family Business Governance in the Middle East: The challenges facing the continuity of family businesses in the Middle East. Trust Trust. 2009, 15, 770-775. [CrossRef]

8. Ward, J. Growing the Family Business: Special Challenges and Best Practices. Fam. Bus. Rev. 1997, 10, 323-338. [CrossRef]

9. Sharma, P.; Chrisman, J.; Gersick, K. 25 Years of Family Business Review: Reflections on the past and perspectives for the future. Fam. Bus. Rev. 2012, 25, 5-15. [CrossRef]

10. Aronoff, C.E. Family Business Survival: Understanding the statistics "only 30\%". Fam. Bus. Advis. 1999, 8, $1-6$.

11. Beckhard, R.; Dyer, W.G. Managing continuity in the family-owned business. Organ. Dyn. 1983, 12, 5-12. [CrossRef]

12. Poza, E.J.; Hanlon, S.; Kishida, R. Does the family business interaction factor represent a resource of a cost? Fam. Bus. Rev. 2004, 17, 99-118. [CrossRef]

13. Tio, J.; Kleiner, B.H. How to be an effective chief executive officer of a family owned business. Manag. Res. News 2005, 28, 142-153. [CrossRef]

14. Baron, J. Why the 21st Century Will Belong to Family Businesses. 28 March 2016. Available online: https: / / hbr.org/2016/03/why-the-21st-century-will-belong-to-family-businesses (accessed on 5 August 2017).

15. Stamm, I.; Lubinski, C. Crossroads of family business research and firm demography: A critical assessment of family business survival rates. J. Fam. Bus. Strategy 2011, 2, 117-127. [CrossRef]

16. Carr, R. Family Business: Setting a Benchmark. June 2012. Available online: http://vision.ae/articles/ family_business_setting_a_benchmark (accessed on 17 March 2016).

17. Sabi, A. The Succession Challenge in GCC Family Business. 14 November 2015. Available online: http: / / globalriskinsights.com/2015/11/the-succession-challenge-in-gcc-family-businesses/ (accessed on 17 March 2016).

18. Pierce, C. What's Holding Back Family Businesses in the GCC? 29 July 2016. Available online: http:/ / gulfnews.com/business/sme/what-s-holding-back-family-businesses-in-the-gcc-1.1870272 (accessed on 9 August 2017).

19. Strike, V.M. Advising the family firm: Reviewing the past to build the future. Fam. Bus. Rev. 2012, 25, 156-177. [CrossRef]

20. Farouk, H. The Rules of Engagement for Family-Owned Businesses. Available online: http://www. grantthornton.ae/page/the-rules-of-engagement-for-family-owned-businesses (accessed on 1 June 2017).

21. Gomez, E.T. Inter-Ethnic Relations, Business and Identity: The Chinnese in Britain and Malaysia; United Nations Research Institute for Social Development: Geneva, Switzerland, 2005.

22. DubaiChamber. Dubai Chamber of Commerce. 2012. Available online: http://web.dubaichamber. ae/LibPublic/Family\%20Businesses\%20in\%20Dubai\%20Definition\%20Structure\%20Performance.pdf (accessed on 23 October 2014).

23. Dyer, W.G.; Sanchez, M. Current state of family business theory and practice as reflected in Family Business Review 1988-1997. Fam. Bus. Rev. 1998, 11, 287-295. [CrossRef] 
24. Salvato, C.; Aldrich, H. That's interesting! in family business research. Fam. Bus. Rev. 2012, 25, $125-135$. [CrossRef]

25. Sharma, P.; Chrisman, J.; Chua, J.H. Strategic managment of the family business: Past research and future challenges. Fam. Bus. Rev. 1997, 10, 1-35. [CrossRef]

26. Xi, J.; Kraus, S.; Filser, M.; Kellermans, F. Mapping the field of family business research: Past trends and future directions. Int. Entrep. Manag. J. 2015, 11, 113-132. [CrossRef]

27. Korsching, P.F.; Allen, J.C. Locality based entrepreneurship: A strategy for cummunity economic vitality. Community Dev. J. 2004, 39, 385-401. [CrossRef]

28. Olson, P.D.; Zuiker, V.S.; Danes, S.M.; Stafford, K.; Heck, R.K.; Duncan, K.A. The impact of the family and business on family business sustainability. J. Bus. Ventur. 2003, 18, 639-666. [CrossRef]

29. Sharma, P. An Overview of the field of Family Business Studies: Currect Status and DIrections for the Future. Fam. Bus. Rev. 2004, 17, 1-35. [CrossRef]

30. Stafford, K.; Bhargava, V.; Danes, S.; Haynes, G.; Brewton, K. Factors associated with long-term survival of family business: Duration analysis. J. Fam. Econ. 2010, 31, 442-457. [CrossRef]

31. Saaty, T. The Analytical Hierarchy Process; McGraw-Hill: New York, NY, USA, 1980.

32. Wrotman, M.S. Critical Issues in Family Business: An International Perspective and Research. In Proceedings of the ICSB 40th World Conference, Sydney, Australia, 18-21 June 1995; pp. 53-76.

33. Davis, J. Definitions and Typologies of the Family Business; Harvard Business School: Boston, MA, USA, 2001.

34. Rettab, B.; Fakhr, T.A.; Morada, M.P. Family Businesses in Dubai: Definition, Structure Performance; Data Management and Research Department; Dubai Chamber of Commerce and Industry: Rigga Al Buteen, Dubai, 2005.

35. Statistics Centre Abu Dhabi. Statistics of Micro, Small, Medium and Large Enterprises. 2013. Available online: https:/ / www.scad.ae/Release\%20Documents/SME\%202013\%20Report\%20-\%20En.pdf (accessed on 6 December 2017).

36. Gersick, K.; Davis, J.; Hampton, M.; Lansberg, I. Generation to Generation: Life Cycle of Family Business; Harvard Business School: Boston, MA, USA, 1997.

37. Abu Dhabi Events Calender. 45th National Day Celebrations. 2016. Available online: https:// abudhabievents.ae/en/Pages/45th-national-day-celebrations.aspx (accessed on 10 December 2016).

38. Augustine, B.D. Middle East's Family Businesses Get Serious on Sustainability. 7 November 2015. Available online: http:/ / gulfnews.com/business/money/middle-east-s-family-businesses-get-serious-onsustainability-1.1614502 (accessed on 10 December 2016).

39. World Commission on Enviroment and Development. Our Common Future the Brundland Report; Oxford University Press: Oxford, UK, 1987.

40. Ward, J. Keeping the Family Business Healthy: How to Plan for Continuing Growth, Profitability, and Family Leadership; Jossey-Bass: San Francisco, CA, USA, 1987.

41. Lambrecht, J.; Lievens, J. Pruning the Family Tree: An unexplored path to family business continuity and family harmony. Fam. Bus. Rev. 2008, 4, 295-313. [CrossRef]

42. Gameno Sandig, A.G.; Labadie, G.J.; Saris, W.; Mayordomo, X.M. Internal factors of family business performance: An integrated theoretical model. In Handbook of Research on Family Business; Poutzioris, P.Z., Smyrnios, K.X., Klein, S.B., Eds.; Edward Elgar Publishing Limited: Cheltenham, UK, 2006; pp. 145-164.

43. Sharma, P.; Chua, J.; Chrisman, J. Perceptions about the extent of succession planning in Canadian family firms. Can. J. Adm. Sci. 2000, 17, 233-244. [CrossRef]

44. Sharma, P.; Chrisman, J.J.; Chua, J.H. Predictors of satisfaction with the succession process in family firms. J. Bus. Ventur. 2003, 18,667-687. [CrossRef]

45. Blumentritt, T.; Mathews, T.; Marchisio, G. Game theory and family business succession: An introduction. Fam. Bus. Rev. 2013, 26, 51-67. [CrossRef]

46. De Massis, A.; Chua, J.H.; Chrisman, J.J. Factors preventing intra-family succession. Fam. Bus. Rev. 2008, 21, 183-199. [CrossRef]

47. Christensen, C. Management Succession in Small and Growing Enterprises; Harvard Business School: Boston, MA, USA, 1953.

48. Trow, D. Executive succession in small Companies. Adm. Sci. Q. 1961, 6, 228-239. [CrossRef]

49. Delmas, A.M.; Gergaud, O. Sustainabile Certification for Future Generations: The Case of Family Business. Fam. Bus. Rev. 2014, 27, 228-243. [CrossRef] 
50. Writer, S. Governance, Succession Issues Still Hound GCCC Family Firms. 22 April 2017. Available online: http:/ / www.arabianbusiness.com/governance-succession-issues-still-hound-gcc-family-firms-671120.html (accessed on 15 August 2017).

51. Sharma, P.; Chrisman, J.; Chua, J. Succession Planning as Planned Behavior: Some Empirical Results. Fam. Bus. Rev. 2003, 16, 1-15. [CrossRef]

52. Ward, J. The special role of strategic Planning for family businesses. Fam. Bus. Rev. 1988, 1, $105-117$. [CrossRef]

53. Astrachan, J.H.; Kolenko, T.A. A neglected factor explaining family business success: Human resource practices. Fam. Bus. Rev. 1994, 7, 251-262. [CrossRef]

54. Blumentritt, T. The relationship between boards and planning in family businesses. Fam. Bus. Rev. 2006, 19, 65-72. [CrossRef]

55. Carlock, R.; Ward, J. Strategic Planning for the Family Business; Palgrave: New York, NY, USA, 2001.

56. Johnson, G.; Scholes, K.; Wittington, R. Exploring Corporate Strategy Text and Cases, 7th ed.; Pearson Edutcation Limited: Harlow, UK, 2005.

57. Eddleston, K.A.; Kellermanns, F.W.; Floyd, S.W.; Crittenden, V.L.; Crittenden, W.F. Planning for growth: Life stage differences in family firms. Entrep. Theory Pract. 2013, 37, 1177-1202. [CrossRef]

58. Price Waterhouse Coopers (PWC) (2016). Addressing the "Missing Middle": Strategic Planning. Available online: https:/ / www.pwc.com/gx/en/services/family-business/family-business-survey-2016/ strategic-planning.html (accessed on 9 August 2017).

59. Aronoff, C.; Ward, J. Family Business Values: How to Assure a Legacy of Continuity and Success; Business Owner Resources: Marietta, GA, USA, 2000.

60. Pieper, T.M. Corporate Governance in Family Firms: A Literature Review; INSEAD Initiative for Family Enterprise: Fontaineblea, France, 2003.

61. Ward, J.L. Good governance is different for family firms. Fam. Bus. 2003, 84-85. Available online: https:/ / www.scholars.northwestern.edu/en/publications / good-governance-is-differentfor-family-firms (accessed on 17 January 2018).

62. Lansberg, I. Succeeding Generations; Harvard Business School Press: Boston, MA, USA, 1999.

63. Rosenblatt, P.C.; De Mik, L.; Anderson, R.M.; Johnson, P.A. The Family in Business; Jossey-Bass: San Francisco, CA, USA, 1985.

64. Mustakallio, M.; Autio, E.; Zahra, S.A. Relational and contractual governance in family firms: Effects on strategic decision making. Fam. Bus. Rev. 2002, 15, 205-222. [CrossRef]

65. Astrachan, J.H.; Klien, S.B.; Smyrnios, K.X. The F-PEC scale of family influence: A proposal for solving the family business definition problem. Fam. Bus. Rev. 2002, 15, 45-58. [CrossRef]

66. Fiedler, F.E. Research on leadership selection and training: One view of the future. Adm. Sci. Q. 1996, 41, 241-250. [CrossRef]

67. Van Der Westhuizen, J.; Garnett, A. The correlation of leadership practices of first and second generation family business owners to business performance. Medterranean J. Soc. Sci. 2014, 5, 323-338. [CrossRef]

68. Yukl, G. Leadership in Organizations; Pearson Education; Prentice Hall Inc.: Upper Saddle River, NJ, USA, 2010.

69. Le Breton-Miller, I.; Miller, D.; Steier, L.P. Toward an integrative model of effective FOB succession. Entrep. Theory Pract. 2004, 28, 305-328. [CrossRef]

70. Lansberg, I. The succession conspiracy. In Family Business Sourcebook II; Anroff, C.E., Astrachan, J.H., Ward, J.L., Eds.; Business Owner Resources: Marietta, GA, USA, 1988; pp. 70-86.

71. Cater, J.J.; Justis, R.T. The development and implementation of shared leadership in multi-generational family firms. Manag. Res. Rev. 2010, 33, 563-585. [CrossRef]

72. Dyck, B.; Mauws, M.; Strake, F.A.; Mischle, G.A. Passing the baton: The importane of sequence, timing, technique and communication in executive sucession. J. Bus. Ventur. 2002, 17, 143-162. [CrossRef]

73. Hartel, E.C.; Bozer, G.; Levin, L. Family business leadership transition: How an adaption of executive coaching may help. J. Manag. Organ. 2009, 15, 278-391.

74. Tapies, J.; Moya, M.F. Values and Longevity in family business: Evidence from a cross-cultural analysis. J. Fam. Bus. Manag. 2012, 2, 130-146. [CrossRef]

75. Koiranen, M. Over 100 years of age but still entrepreneurially active in business: Exploring the values and family characteristics of old Finnish family firms. Fam. Bus. Rev. 2002, 15, 175-187. [CrossRef] 
76. Lansberg, I.S. Managing human resources in family firms: The problem of institutional overlap. Organ. Dyn. 1983, 12, 39-46. [CrossRef]

77. Erdem, F.; Baser, G.G. Family and business values of reginal family firms: A qualitative research. Int. J. Islam. Middle Eastern Financ. Manag. 2010, 3, 47-64. [CrossRef]

78. Miller, D.; Le Breton-Miller, I. Managing for the Long Run: Lessons in Competitive Advantage from Great Family Businesses; Harvard Business School Press: Boston, MA, USA, 2005.

79. Danes, S.; Lee, J.; Stafford, K.; Heck, R. The effects of ethnicity, families and culture on entrepreneurial experience: An extension of Sustainable Family Business Theory. J. Dev. Entrep. 2008, 13, 2229-2268. [CrossRef]

80. Danes, S.; Stafford, K.; Haynes, G.; Amarapurkar, S. Family Capital of Family Firms, Bridging Human, Social and Financial Capital. Fam. Bus. Rev. 2009, 22, 199-215. [CrossRef]

81. Portes, A. Social Capital: Its Orgins and applications in modern Socilogy. Annu. Rev. Sociol. 1998, $24,1-24$. [CrossRef]

82. Hoffman, J.; Hoelscher, M.; Sorenson, R. Achieving sustained competitive advantage: A family capital theory. Fam. Bus. Rev. 2006, 19, 135-145. [CrossRef]

83. Sirmon, D.G.; Hitt, M.A. Managing resources: Linking unique resources, management, and wealth creation in family firms. Entrep. Theory Pract. 2003, 27, 339-358. [CrossRef]

84. Stavrou, E.T. Succession in family businesses: Exploring the effects of demographic factors on offspring intentions to join and take over the business. J. Small Bus. Manag. 1999, 37, 43-61.

85. Alder, S.; Kwon, S. Social Capital: Prospects for a new concept. Acad. Manag. Rev. 2002, 27, 17-40.

86. Sorenson, R.L.; Bierman, L. Family capital, family business, free enterprise. Fam. Bus. Rev. 2009, 22, $193-195$. [CrossRef]

87. Astrachan, J.H.; McMillan, K.S. Handbook of Family Business Family Business Consultation: A Global Perspective; Kaslow, F.W., Ed.; International Business Press: Binghamton, NY, USA, 2006; pp. 347-363.

88. Craig, J.B.; Moores, K. Championing family business issues to influence public policy: Evidence from Australia. Fam. Bus. Rev. 2010, 23, 170-180. [CrossRef]

89. LaChapelle, K.; Barnes, L.B. The trust catalyst in family-owned businesses. Fam. Bus. Rev. 1998, 11, 1-17. [CrossRef]

90. Kaye, K.; Hamilton, S. Roles of trust in consulting to financial famlies. Fam. Bus. Rev. 2004, 17, 151-163. [CrossRef]

91. Bork, D.; Jaffe, D.; Lane, S.; Dashew, L.; Heilser, Q. Working with Family Businesses; Jossey-Bass: San Francisco, CA, USA, 1996.

92. Hilburt-Davis, J.; Dyer, W.G. Consulting to Family Businesses: A Practical Guide to Contracting, Assessment and Implementation; Jossey-Bass/Pfeiffer: San Francisco, CA, USA, 2003.

93. Le Breton Miller, I.; Miller, D. Agency vs. stewardship in public family firms: Social embeddedness reconciliation. Entrep. Theory Pract. 2009, 33, 1169-1191. [CrossRef]

94. Reay, T.; Pearson, A.; Dyer, W. Advising Family Enterprise: Examining the Role of Family Firm Advisors. Fam. Bus. Rev. 2013, 29, 209-214. [CrossRef]

95. Chin, K.S.; Chiu, S.; Tummala, V. An evaluation of success factors using AHP to implement ISO 14001-based ESM. Int. J. Qual. Reliab. Manag. 1999, 16, 341-361. [CrossRef]

96. Alessio, I.; Craig, P.; Philippe, N. AHPSort: An AHP-based method for sorting problems. Int. J. Prod. Res. 2012, 50, 4767-4784.

97. Hussain, M.; Ajmal, M.M.; Khan, M.; Hussein, S. Competitive Priorities and Knowledge Management: An Empirical Investigation of Manufacturing Companies in UAE. J. Manuf. Technol. Manag. 2015, 26, 791-806. [CrossRef]

98. Hussain, M.; Malik, M.; Al Neyadi, H.S. AHP framework to assist lean deployment in Abu Dhabi public healthcare delivery system. Bus. Process Manag. J. 2016, 22, 546-565. [CrossRef]

99. AlDhaheri, R.; Jabeen, F.; Hussain, M.; Abu-Rahma, A. Career choice of females in the private sector: Empirical evidence from the United Arab Emirates. Higher Educ. Skills Work-Based Learn. 2017, 7, 179-197. [CrossRef]

100. Saaty, T.L.; Vargas, L.G. Models, Methods, Concepts Applications of the Analytic Hiererchy Process; Kluwer Academic Publishers: Boston, MA, USA, 2001. 
101. Saaty, T.L. How to make a decision: The analytic hierarchy process. Eur. J. Oper. Res. 1990, 48, 9-26. [CrossRef]

102. Saaty, T.L. Decision Making for Leaders: The Analytic Hierarchy Process for Decisions in a Complex World; RWS Publications: Pittsburgh, PA, USA, 2012.

103. Stake, R. The Art of Case Study Research; Sage: Thousand Oaks, CA, USA, 1995; p. 57.

104. Neubauer, H. The dynamics of succession in family business in western European countries. Fam. Bus. Rev. 2003, 16, 269-281. [CrossRef]

105. Buchloz, B.; Crane, M.; Nager, R. The Family Business Answer Book; Prentice Hall Press: Upper Saddle River, NJ, USA, 1999.

106. Sarbah, A.; Xio, W. Good Corporate Governance Structures: A must for Family businesses. J. Bus. Manag. 2015, 3, 40-57. [CrossRef]

107. Hofstede, G. Culture's Consequences: International Differences in Work-Related Values; Sage Publications, Inc.: Beverly Hills, CA, USA, 1980.

(C) 2018 by the authors. Licensee MDPI, Basel, Switzerland. This article is an open access article distributed under the terms and conditions of the Creative Commons Attribution (CC BY) license (http:/ / creativecommons.org/licenses/by/4.0/). 